\title{
Pharmacological Properties of FK886, a New, Centrally Active Neurokinin-1 Receptor Antagonist
}

\author{
Takako Yoshino-Furukawa, ${ }^{* \dagger}$ Yasue Maeda, Aya Kikuchi, Hiroyuki Sakuma, Katsunori Imazumi, \\ Hisashi Yamakuni, Hajime Sogabe, Masahiko Matsuo, " Toshitaka Manda," and Wataru Uchida \\ Pharmacology Research Laboratories, Drug Discovery Research, Astellas Pharma Inc.; 21 Miyukigaoka, Tsukuba, \\ Ibaraki 305-8585, Japan. \\ Received July 18, 2012; accepted October 24, 2012
}

The pharmacological properties of the novel neurokinin-1 $\left(\mathrm{NK}_{1}\right)$ receptor antagonist FK886, ([3,5-bis(trifluoromethyl)phenyl][(2R)-2-(3-hydroxy-4-methylbenzyl)-4-\{2-[(2S)-2-(methoxymethyl)morpholin-4-yl]ethyl\}piperazin-1-yl]methanone dihydrochloride), were studied. FK886 potently inhibited the binding of $\left[{ }^{125} \mathrm{I}\right]$ Bolton-Hunter-labeled substance $\mathrm{P}\left(\left[{ }^{125} \mathrm{I}\right] \mathrm{BH}-\mathrm{SP} ; 100 \mathrm{pM}\right)$ to human $\mathrm{NK}_{1}$ receptors expressed in Chinese hamster ovary $(\mathrm{CHO})$ cells $\left(\mathrm{IC}_{50}=0.70 \mathrm{~nm}\right)$. It also possessed high affinities for dog, ferret, gerbil and guinea pig $\mathrm{NK}_{1}$ receptors, but not for rat $\mathrm{NK}_{1}$ receptor. FK886 was highly selective for the $\mathrm{NK}_{1}$ receptor, with 250- and $>20000$-fold selectivity for human $\mathrm{NK}_{1}$ over $\mathrm{NK}_{2}$ and $\mathrm{NK}_{3}$, respectively. Further, it did not inhibit radioligand binding at 54 different sites, including receptors, ion channels and transporters. FK886 inhibited substance $\mathrm{P}(3.2 \mathrm{nM})$-induced inositol phosphate formation in human $\mathrm{NK}_{1}$ receptor-expressing $\mathrm{CHO}$ cells $\left(\mathrm{IC}_{50}=1.4 \mathrm{nM}\right)$ without stimulating $\mathrm{NK}_{1}$ receptors. The antagonism exerted by FK886 against human $\mathrm{NK}_{1}$ receptor was insurmountable in saturation binding experiments, with both the affinity and $B_{\max }$ of $\left[{ }^{125} \mathrm{I}\right] \mathrm{BH}-\mathrm{SP}$ being significantly reduced. After intravenous administration, FK886 (0.01-0.1 mg/ $\mathrm{kg})$ dose-dependently inhibited the foot-tapping behavior induced by intracerebroventricular administration of a selective $\mathrm{NK}_{1}$ receptor agonist, GR73632 $(10 \mathrm{pmol})$, in gerbils, with significant inhibition being observed at doses of $0.032-0.1 \mathrm{mg} / \mathrm{kg}$, indicating excellent brain penetration. The brain penetration of FK886 was further demonstrated by the cerebral distribution of radioactivity after intravenous injection of radiolabeled FK886. Taken together, these results demonstrate that FK886 is a potent, highly selective and centrally active, insurmountable antagonist of the $\mathrm{NK}_{1}$ receptor, and suggest that $\mathrm{FK886}$ antagonizes various $\mathrm{NK}_{1}$ receptor-mediated biological effects in the central nervous system.

Key words FK886; neurokinin-1 antagonist; neurokinin receptor; substance P; tachykinin

Substance P (SP) belongs to a group of related neuropeptides named tachykinins, which include neurokinin A (NKA) and neurokinin $\mathrm{B}(\mathrm{NKB})$. These peptides are widely distributed in the central and peripheral nervous systems, where they act as neurotransmitters or neuromodulators. Tachykinins exert their biological effect via the activation of three different $\mathrm{G}$ protein-coupled neurokinin $(\mathrm{NK})$ receptors: $\mathrm{NK}_{1}, \mathrm{NK}_{2}$ and $\mathrm{NK}_{3}$, which preferentially bind to SP, NKA and NKB, respectively. ${ }^{1,2)}$ Recent clinical and preclinical studies have noted that central $\mathrm{NK}_{1}$ receptor activation is associated with various pathological functions such as pain, anxiety/depression and emesis. ${ }^{3-6)}$

Previously, Manabe et al. reported a potent non-peptide $\mathrm{NK}_{1}$ receptor antagonist, FK355, 2-[(3R)-4-[3,5-bis(trifluoromethyl)benzoyl]-3-(1H-indol-3-ylmethyl)piperazin-1yl]-N-(4-methylpiperazin-1-yl)acetamide $(2 E)$-but-2-enedioate $(1: 1)$ (Fig. 1A), which was developed by the chemical modification of a high affinity dipeptide $\mathrm{NK}_{1}$ receptor antagonist, FK888. ${ }^{7)}$ FK 355 potently and selectively inhibited SP binding to $\mathrm{NK}_{1}$ receptors in vitro and potently inhibited SPinduced plasma extravasation in guinea pig in vivo. Because FK355 and its derivatives displayed poor brain penetration,

\footnotetext{
The authors declare no conflict of interest.

† Present address: Analysis \& Pharmacokinetics Research Laboratories, Drug Discovery Research, Astellas Pharma Inc.; 21 Miyukigaoka, Tsukuba, Ibaraki 305-8585, Japan.

${ }^{\ddagger}$ Present address: Astellas Research Technologies Co., Ltd.; 21 Miyukigaoka, Tsukuba, Ibaraki 305-8585, Japan.
}

we investigated the development of alternative $\mathrm{NK}_{1}$ receptor antagonists using FK355 as the template. Here, we report the pharmacological properties of a new compound, FK886, [3,5-bis(trifluoromethyl)phenyl][(2R)-2-(3-hydroxy-4methylbenzyl)-4-\{2-[(2S)-2-(methoxymethyl)morpholin-4-yl]ethyl\}piperazin-1-yl]methanone dihydrochloride ${ }^{8)}$ (Fig. 1B), a potent, highly selective and centrally active, insurmountable antagonist of the $\mathrm{NK}_{1}$ receptor that can antagonize various $\mathrm{NK}_{1}$ receptor-mediated biological effects in the central nervous system (CNS). We describe the in vitro and in vivo pharmacological properties of FK886 below.

\section{MATERIALS AND METHODS}

Materials FK886 and FK355 were synthesized at Chemistry Research Laboratories, Astellas Pharma Inc. $\left[{ }^{14} \mathrm{C}\right] \mathrm{FK} 886 \quad(1.06 \mathrm{MBq} / \mathrm{mg})$ and $\left[{ }^{14} \mathrm{C}\right] \mathrm{FK} 355 \quad(1.19 \mathrm{MBq} / \mathrm{mg})$ were synthesized at GE Healthcare U.K. (Buckinghamshire, England) and Sekisui Medical (Tokyo, Japan), respectively. SP and NKA were obtained from Peptide Institute (Osaka, Japan). GR73632 was obtained from Sigma-Aldrich (St. Louis, MO, U.S.A.). $\left.{ }^{125} \mathrm{I}\right]$ Bolton-Hunter-labeled substance P ([ $\left.\left[{ }^{125} \mathrm{I}\right] \mathrm{BH}-\mathrm{SP} ; \quad 81.4 \mathrm{TBq} / \mathrm{mmol}\right), \quad\left[{ }^{125} \mathrm{I}\right] \mathrm{NKA} \quad(81.4 \mathrm{TBq} / \mathrm{mmol})$, and $\left[{ }^{125} \mathrm{I}\right] \mathrm{MePhe}-\mathrm{NKB}\left(\left[{ }^{125} \mathrm{I}\right] \mathrm{NKB} ; 81.4 \mathrm{TBq} / \mathrm{mmol}\right)$ were purchased from PerkinElmer (Boston, MA, U.S.A.), and myo-[2$\left.{ }^{3} \mathrm{H}\right]$ inositol $(666 \mathrm{GBq} / \mathrm{mmol})$ was purchased from GE Healthcare U.K. (Buckinghamshire, England).

FK886 and FK355 were dissolved in dimethylsulfoxide (DMSO) and then diluted into respective assay buffers such 


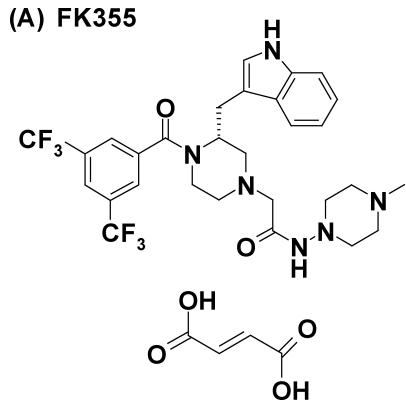

Fig. 1. Chemical Structures of (A) FK355 and (B) FK886

that the final DMSO concentration did not exceed $0.1 \%$ in any in vitro experiment. For in vivo studies, FK886, FK355 and GR73632 were dissolved in saline.

NK$_{1}$ Receptor Binding Human $\mathrm{NK}_{1}$ receptors were cloned and stably expressed in Chinese hamster ovary (CHO) cells as described previously. ${ }^{9)}$ All subsequent steps were performed at $4{ }^{\circ} \mathrm{C}$. Cells were harvested and homogenized in $25 \mathrm{~mm}$ Tris- $\mathrm{HCl}$ buffer, $\mathrm{pH} 7.4$, containing $10 \mathrm{~mm} \mathrm{MgCl}_{2}$, $1 \mathrm{~mm}$ ethylenediaminetetraacetic acid (EDTA), $5 \mu \mathrm{g} / \mathrm{mL} p$ amidinophenyl methansulfonyl fluoride ( $p$-APMSF) and $0.25 \mathrm{M}$ sucrose. The homogenate was centrifuged at $500 \times \boldsymbol{g}$ for $10 \mathrm{~min}$, and the supernatant was further centrifuged at $100000 \times \mathbf{g}$ for $60 \mathrm{~min}$. The final pellet was resuspended in $25 \mathrm{~mm}$ Tris- $\mathrm{HCl}$ buffer, $\mathrm{pH} 7.4$, containing $10 \mathrm{~mm} \mathrm{MgCl}_{2}$, $1 \mathrm{~mm}$ EDTA and $5 \mu \mathrm{g} / \mathrm{mL} p$-APMSF. To prepare forebrain membranes of dog, ferret, gerbil, guinea pig, and rat, tissue samples were homogenized in $1 \mathrm{~mm}$ potassium phosphate buffer, $\mathrm{pH} 7.5$, containing $0.1 \mathrm{~mm}$ EDTA and $0.32 \mathrm{M}$ sucrose. The homogenate was centrifuged at $1000 \times \boldsymbol{g}$ for $10 \mathrm{~min}$, and the supernatant was centrifuged at $20000 \times \boldsymbol{g}$ for $20 \mathrm{~min}$. The pellet was suspended in purified water and kept on ice for $45 \mathrm{~min}$, followed by re-homogenization and centrifugation at $8000 \times \boldsymbol{g}$ for $20 \mathrm{~min}$. The supernatant was collected and centrifuged at $25000 \times \boldsymbol{g}$ for $20 \mathrm{~min}$. The pellet was suspended with $5 \mathrm{~mm}$ Tris- $\mathrm{HCl}$ buffer, $\mathrm{pH} 7.5$, and centrifuged at $25000 \times \boldsymbol{g}$ for $20 \mathrm{~min}$. This washing process was repeated twice and the final pellet was suspended with $5 \mathrm{~mm}$ Tris- $\mathrm{HCl}$ buffer, $\mathrm{pH}$ 7.5. Binding of $\left[{ }^{125} \mathrm{I}\right] \mathrm{BH}-\mathrm{SP}$ to $\mathrm{NK}_{1}$ receptors was evaluated by incubating the membrane preparation $(6 \mu \mathrm{g}$ protein for human and $90-150 \mu \mathrm{g}$ protein for dog, ferret, gerbil, guinea pig and rat) with $100 \mathrm{pm}\left[{ }^{125} \mathrm{I}\right] \mathrm{BH}-\mathrm{SP}$ in $250 \mu \mathrm{L}$ assay buffer $(50 \mathrm{~mm}$ Tris-HCl buffer, $\mathrm{pH} 7.4$, containing $5 \mathrm{mM} \mathrm{MnCl}_{2}, 0.2 \mathrm{mg} / \mathrm{mL}$ bovine serum albumin (BSA), $5 \mu \mathrm{g} / \mathrm{mL} p$-APMSF, $4 \mu \mathrm{g} / \mathrm{mL}$ leupeptin, $40 \mu \mathrm{g} / \mathrm{mL}$ bacitracin and $20 \mu \mathrm{g} / \mathrm{mL}$ chymostatin) for $90 \mathrm{~min}$ (human) or $30 \mathrm{~min}$ (dog, ferret, gerbil, guinea pig, and rat) at room temperature. Nonspecific binding was determined in the presence of $3 \mu \mathrm{M}$ non-radioactive SP. The reaction was terminated by rapid filtration through a glass fiber filter pretreated with $0.1 \%$ polyethyleneimine. The filter was washed with $50 \mathrm{~mm}$ Tris- $\mathrm{HCl}$ buffer, $\mathrm{pH} 7.4$, containing $5 \mathrm{~mm} \mathrm{MnCl}_{2}$ and dried. Radioactivity was counted with a $\gamma$-counter. Each binding assay was carried out three times in duplicate.

$\mathrm{NK}_{2}$ and $\mathrm{NK}_{3}$ Receptor Binding Cell membranes were prepared from human $\mathrm{NK}_{2}$ or $\mathrm{NK}_{3}$ receptor-expressing $\mathrm{CHO}$ cells using the same procedure as that for the $\mathrm{NK}_{1}$ membrane preparation. Binding assays for human $\mathrm{NK}_{2}$ and $\mathrm{NK}_{3}$ receptors were performed similarly to the $\mathrm{NK}_{1}$ binding assay except for the following. For the $\mathrm{NK}_{2}$ receptor, the
(B) FK886

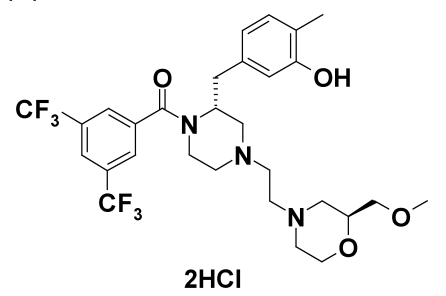

membrane preparation (16 $\mu \mathrm{g}$ protein) was incubated with $100 \mathrm{pm} \quad\left[{ }^{125} \mathrm{I}\right] \mathrm{NKA}$ for $30 \mathrm{~min}$ and nonspecific binding was determined in the presence of $3 \mu \mathrm{m}$ non-radioactive NKA. For the $\mathrm{NK}_{3}$ receptor, the membrane preparation $(10 \mu \mathrm{g}$ protein) was incubated with $100 \mathrm{pm}\left[{ }^{125} \mathrm{I}\right] \mathrm{NKB}$ for $60 \mathrm{~min}$ and nonspecific binding was determined in the presence of $3 \mu \mathrm{M}$ of nonradioactive NKB. Glass fiber filters for rapid filtration were pretreated with $0.2 \%$ BSA.

Binding to Receptors, Ion Channels and Transporters Unrelated to Tachykinin In order to determine the selectivity of FK886, binding assays for 55 binding sites of receptors, ion channels, and transporters were conducted at Daiichi Pure Chemicals (Tokyo, Japan) according to their established proprietary protocols. The respective assay conditions are summarized in Table 3.

In Vitro Functional Assay The antagonist activity of FK886 was determined by measuring the FK886 inhibition of SP-induced inositol phosphate formation in human $\mathrm{NK}_{1}$ receptor-expressing CHO cells. ${ }^{9)}$ The cells were seeded at $1 \times 10^{5} \mathrm{cells} /$ well in 12 -well plates in alpha-modified minimal essential medium supplemented with $10 \%$ fetal calf serum and cultured for one day. Cells were cultured for a further $18-24 \mathrm{~h}$ in the labeling medium supplemented with $37 \mathrm{KBq} / \mathrm{mL}$ myo$\left[2-{ }^{3} \mathrm{H}\right]$ inositol. Prior to the assays, cells were washed twice with phosphate-buffered saline (PBS) containing 0.2\% BSA and incubated in the same buffer for $30 \mathrm{~min}$ at $37^{\circ} \mathrm{C}$. The cells were preincubated with FK886 $(0.32-100 \mathrm{nM})$ in assay buffer (PBS containing $0.2 \% \mathrm{BSA}$ and $10 \mathrm{~mm} \mathrm{LiCl}$ to prevent phosphatidylinositol breakdown) for $30 \mathrm{~min}$ at $37^{\circ} \mathrm{C}$. Agonist stimulation was started by replacement of assay buffer with fresh assay buffer that included $3.2 \mathrm{~nm} \mathrm{SP}$ and FK886. After $30 \mathrm{~min}$ incubation at $37^{\circ} \mathrm{C}$, the assay was terminated by removing the assay buffer and the addition of $1 \mathrm{~mL}$ of $5 \%(\mathrm{w} / \mathrm{v})$ trichloroacetic acid. After $1 \mathrm{~h}$ on ice, the resulting extracts from each well were transferred to glass tubes. The extracts were washed twice with $2 \mathrm{~mL}$ water-saturated diethyl ether to remove trichloroacetic acid, mixed with $150 \mu \mathrm{L} 0.2 \mathrm{M}$ Tris-base and applied to anion exchange resin (AG1-X8 formate, Bio-Rad Laboratories, Hercules, CA, U.S.A.) columns. The columns were washed with $10 \mathrm{~mL}$ of water followed by $5 \mathrm{~mL}$ of $5 \mathrm{~mm}$ sodium tetraborate $-60 \mathrm{~mm}$ sodium formate to remove free inositol and glycerophosphoinositide, respectively. The total inositol phosphate was eluted with $2.5 \mathrm{~mL}$ of $0.1 \mathrm{M}$ formic acid- $1 \mathrm{M}$ ammonium formate. The radioactivity of the eluate was measured with a liquid scintillation counter. Assays were repeated three times. In order to pool data across individual experiments, the radioactivity of inositol phosphate in the presence of SP was expressed as the fold increase in radioactivity compared to the 
corresponding control (in the absence of SP).

Animals Seven-week-old male gerbils (Japan SLC, Shizuoka, Japan) and 7-week-old male Sprague-Dawley rats (CLEA Japan, Tokyo, Japan) were used. The animals were acclimated for one week prior to the experiments. The animals were maintained in a temperature- and humidity-controlled room with a $12: 12 \mathrm{~h}$ light/dark cycle (lights on 07:00-19:00 h). Food and water were available ad libitum. All animal experimental procedures were approved by the Institutional Animal Care and Use Committee of Astellas Pharma Inc.

GR73632-Induced Foot Tapping in Gerbils Under light ether anesthesia, the jugular vein was exposed and an incision was made in the midline of the scalp to expose the skull. GR73632 (10 pmol in $5 \mu \mathrm{L})$ was injected directly into the lateral ventricle (i.c.v.) via a cuffed microsyringe vertically inserted $4.5 \mathrm{~mm}$ below the bregma. FK886 $(0.01-0.1 \mathrm{mg} / \mathrm{kg})$, FK355 $(0.32-3.2 \mathrm{mg} / \mathrm{kg})$ or vehicle (saline) was administered via the jugular vein $(10 \mathrm{~mL} / \mathrm{kg}) 1 \mathrm{~min}$ prior to the GR73632 injection. Otherwise, FK355 $(1-100 \mathrm{nmol}$ in $5 \mu \mathrm{L})$ or vehicle ( $5 \mu \mathrm{L}$ of saline) was administered intracerebroventricularly $1 \mathrm{~min}$ before GR73632 injection. The duration of repetitive and persistent foot tapping was recorded from immediately after agonist injection over a 60 -min period. If the repetitive foottapping behavior was separated by at least $30 \mathrm{~s}$, the behavior was considered discontinued.

Tissue Distribution of $\left[{ }^{14} \mathrm{C}\right] \mathrm{FK886}$ and $\left[{ }^{14} \mathrm{C}\right] \mathrm{FK} 355$ in Rats Rats were deprived of food but not water overnight prior to injection. Injection of $\left[{ }^{14} \mathrm{C}\right] \mathrm{FK} 886(3.2 \mathrm{mg} / 1.13 \mathrm{MBq} /$ $\mathrm{mL} / \mathrm{kg})$ or $\left[{ }^{14} \mathrm{C}\right] \mathrm{FK} 355(1 \mathrm{mg} / 1.19 \mathrm{MBq} / \mathrm{mL} / \mathrm{kg})$ was made via the tail vein, and blood samples were collected from the aorta under ether anesthesia $5 \mathrm{~min}$ after the injection. The cerebrum was removed from each animal, weighed and prepared as $10 \%(\mathrm{w} / \mathrm{v})$ aqueous homogenate. Aliquots $(100 \mu \mathrm{L})$ of each plasma and cerebrum homogenate were solubilized in $1 \mathrm{~mL}$ Soluene-350 (PerkinElmer, Boston, MA, U.S.A.) and mixed with $10 \mathrm{~mL}$ Econofluor (PerkinElmer). The radioactivity of the samples was counted with a liquid scintillation counter. The background was obtained from the samples of non-treated animals. Twice the mean background was assumed to be the lower detection limit.

Data Analysis Results are expressed as the mean \pm S.E.M. unless otherwise noted. $\mathrm{IC}_{50}$ values were calculated by the linear regression of log-logit-transformed concentration response curves over the range of 5-95\% maximal effect. Significance was assessed by one-way analysis of variance followed by Dunnett's multiple comparison test.

\section{RESULTS}

Binding Studies FK886 inhibited $\left[{ }^{125} \mathrm{I}\right] \mathrm{BH}-\mathrm{SP}$ binding to recombinant human $\mathrm{NK}_{1}$ receptors in a concentrationdependent manner that yielded an $\mathrm{IC}_{50}$ value of $0.70 \mathrm{~nm}$ (Table 1), which is almost identical to the affinity of the values measured for FK888 and FK355. FK886 also possessed high affinity for dog, ferret, gerbil, and guinea pig $\mathrm{NK}_{1}$ receptors, but 30 -fold lower affinity for rat $\mathrm{NK}_{1}$ receptor (Table 2).

The $\mathrm{IC}_{50}$ values of $\mathrm{FK} 886$ for the $\mathrm{NK}_{2}$ and $\mathrm{NK}_{3}$ receptors were 250 - and $>20000$-fold lower than that measured for the human $\mathrm{NK}_{1}$ receptor, respectively (Table 1). FK886 did not inhibit $\left(\mathrm{IC}_{50}>1 \mu \mathrm{M}\right)$ radioligand binding at 54 different sites, including receptors, ion channels and transporters (Table 3).
Table 1. Affinities of FK Compounds for Human Recombinant $\mathrm{NK}_{1}$, $\mathrm{NK}_{2}$ and $\mathrm{NK}_{3}$ Receptors

\begin{tabular}{cccc}
\hline \hline & & \multicolumn{2}{c}{$\mathrm{IC}_{50}(\mathrm{~nm})$} \\
\cline { 3 - 4 } Compound & Receptor & Mean & $\begin{array}{c}95 \% \text { Confidence } \\
\text { interval (nM) }\end{array}$ \\
\hline \multirow{2}{*}{ FK886 } & $\mathrm{NK}_{1}$ & 0.70 & $0.62-0.78$ \\
& $\mathrm{NK}_{2}$ & 180 & $87-280$ \\
& $\mathrm{NK}_{3}$ & $>15000$ & \\
FK888 & $\mathrm{NK}_{1}$ & 3.1 & $2.8-3.3$ \\
FK355 & $\mathrm{NK}_{1}$ & 1.4 & $1.3-1.6$ \\
\hline
\end{tabular}

Values were obtained from three separate experiments performed in duplicate.

Table 2. Affinity of FK886 for $\mathrm{NK}_{1}$ Receptors from Various Animal Species

\begin{tabular}{lcc}
\hline \hline \multirow{2}{*}{ Source } & \multicolumn{2}{c}{$\mathrm{IC}_{50}(\mathrm{~nm})$} \\
\cline { 2 - 3 } & Mean & $\begin{array}{c}95 \% \text { Confidence interval } \\
(\mathrm{nm})\end{array}$ \\
\hline Dog forebrain & 1.0 & $1.0-1.0$ \\
Ferret forebrain & 1.3 & $1.1-1.6$ \\
Gerbil forebrain & 1.0 & $0.94-1.1$ \\
Guinea pig forebrain & 1.3 & $1.1-1.6$ \\
Rat forebrain & 23.0 & $20-25$ \\
\hline
\end{tabular}

Values were obtained from three separate experiments performed in duplicate.

Although FK886 interacted weakly with sodium channel site 2 in guinea pig heart, affinity $\left(\mathrm{IC}_{50}=0.87 \mu \mathrm{M}\right)$ was more than 1000 -fold lower than that measured for human $\mathrm{NK}_{1}$ receptors.

Scatchard analysis of the data for saturation binding of $\left[{ }^{125} \mathrm{I}\right] \mathrm{BH}-\mathrm{SP}$ to human $\mathrm{NK}_{1}$ receptors in the absence and presence of increasing concentrations $(0.2-0.6 \mathrm{nM})$ of FK886 demonstrated that the antagonism exerted by FK886 was insurmountable. ${ }^{10,11)}$ FK886 produced a concentration-dependent and significant increase in the $K_{\mathrm{d}}$ value (i.e., reduction in the affinity) of the radio-labeled SP, with a concomitant and significant reduction in maximal binding $\left(B_{\max }\right)$ (Table 4$)$.

In Vitro Functional Assay The functional activity of FK886 at the human $\mathrm{NK}_{1}$ receptor was assessed by its ability to inhibit SP-induced inositol phosphate formation in human $\mathrm{NK}_{1}$ receptor-expressing $\mathrm{CHO}$ cells. SP (3.2 nM) provoked a 25 -fold increase in intracellular $\left[{ }^{3} \mathrm{H}\right]$ inositol phosphate in these cells and was inhibited by FK886 in a concentrationdependent manner (Fig. 2). The $\mathrm{IC}_{50}$ value was $1.4 \mathrm{~nm}$. FK886 itself had no stimulatory activity at concentrations up to $10 \mu \mathrm{M}$ (data not shown).

GR73632-Induced Foot Tapping in Gerbils The ability of FK886 to block central $\mathrm{NK}_{1}$ receptor activation was evaluated by measuring FK886 activity toward the foot-tapping behavior induced by the central administration of a potent and selective $\mathrm{NK}_{1}$ agonist, GR73632, in gerbils. To observe the duration of action of the compounds on central $\mathrm{NK}_{1}$ receptors, we set the observation period to $60 \mathrm{~min}$, which is much longer than that of previous studies. As for the dose of GR73632, 10 pmol was chosen to induce long-lasting foot tapping. Direct injection of GR73632 to the brain induced constant foottapping behavior, with a $45-50 \mathrm{~min}$ tapping time during the 60-min observation period. Intravenously administered FK886 (0.01-0.1 mg/kg) decreased the tapping time dose-dependently, with a significant decrease observed at doses of $0.032 \mathrm{mg} /$ $\mathrm{kg}$ or higher (Fig. 3A). Furthermore, foot tapping was nearly 
Table 3. Affinity of FK886 for Various Receptors, Ion Channels and Transporters Unrelated to Tachykinin Receptors

\begin{tabular}{|c|c|c|c|}
\hline Binding site & Source & Radio ligand & $\mathrm{IC}_{50}(\mu \mathrm{M})$ \\
\hline Adenosine $\mathrm{A}_{1}$ & Rat brain & {$\left[{ }^{3} \mathrm{H}\right] \mathrm{CCPA}(7 \mathrm{~nm})$} & $>1$ \\
\hline Adenosine $\mathrm{A}_{2}$ & Rat striatum & {$\left[{ }^{3} \mathrm{H}\right] \mathrm{CGS}-21680(6 \mathrm{~nm})$} & $>1$ \\
\hline Adenosine $\mathrm{A}_{3}$ & Rat recombinant & {$\left[{ }^{125} \mathrm{I}\right] \mathrm{AB}-\mathrm{MECA}(1 \mathrm{nM})$} & $>1$ \\
\hline$\alpha_{1}$-Adrenergic (non-selective) & Rat brain & {$\left[{ }^{3} \mathrm{H}\right] \operatorname{Prazosin}(0.5 \mathrm{~nm})$} & $>1$ \\
\hline$\alpha_{2}$-Adrenergic (non-selective) & Rat cerebral cortex & {$\left[{ }^{3} \mathrm{H}\right] \mathrm{RX} 821002(1 \mathrm{~nm})$} & $>1$ \\
\hline$\beta$-Adrenergic (non-selective) & Rat brain & {$\left[{ }^{3} \mathrm{H}\right] \mathrm{DHA}(0.5 \mathrm{~nm})$} & $>1$ \\
\hline Angiotensin II (type 1) & Human recombinant & {$\left[{ }^{125} \mathrm{I}\right]$ Angiotensin II $(0.15 \mathrm{~nm})$} & $>1$ \\
\hline Angiotensin II (type 2) & Human recombinant & {$\left[{ }^{125} \mathrm{I}\right] \mathrm{CGP} 42112 \mathrm{~A}(0.02 \mathrm{~nm})$} & $>1$ \\
\hline Bradykinin $\mathrm{B}_{2}$ & Human recombinant & {$\left[{ }^{3} \mathrm{H}\right]$ Bradykinin $(0.2 \mathrm{~nm})$} & $>1$ \\
\hline Ca channel (L, benzothiazepine) & Rat cerebral cortex & {$\left[{ }^{3} \mathrm{H}\right]$ Diltiazem $(2.5 \mathrm{~nm})$} & $>1$ \\
\hline Ca channel (L, benzothiazepine) & Guinea pig heart & {$\left[{ }^{3} \mathrm{H}\right]$ Diltiazem $(2.5 \mathrm{~nm})$} & $>1$ \\
\hline Ca channel $(\mathrm{N})$ & Rat cerebral cortex & {$\left[{ }^{125} \mathrm{I}\right] \omega$-Conotoxin $(0.005 \mathrm{~nm})$} & $>1$ \\
\hline Ca channel $(\mathrm{N})$ & Guinea pig heart & {$\left[{ }^{125} \mathrm{I}\right] \omega$-Conotoxin $(0.005 \mathrm{~nm})$} & $>1$ \\
\hline Cholecystokinin A & Human recombinant & {$\left[{ }^{3} \mathrm{H}\right] \mathrm{L}-364718(0.5 \mathrm{~nm})$} & $>1$ \\
\hline Dopamine $\mathrm{D}_{1}$ & Rat striatum & {$\left[{ }^{3} \mathrm{H}\right] \mathrm{SCH}-23390(0.5 \mathrm{~nm})$} & $>1$ \\
\hline Dopamine $\mathrm{D}_{2}$ & Rat striatum & {$\left[{ }^{3} \mathrm{H}\right]$ Spiperone $(2 \mathrm{~nm})$} & $>1$ \\
\hline Dopamine transporter & Human recombinant & {$\left[{ }^{3} \mathrm{H}\right]$ WIN35428 (2.5 nM) } & $>1$ \\
\hline Estrogen & Rat uterine & {$\left[{ }^{3} \mathrm{H}\right] \beta$-Estradiol $(1 \mathrm{~nm})$} & $>1$ \\
\hline Endothelin A & Human recombinant & {$\left[{ }^{125} \mathrm{I}\right]$ Endothelin-1 (0.1 nM) } & $>1$ \\
\hline Endothelin B & Human recombinant & {$\left[{ }^{125} \mathrm{I}\right]$ Endothelin-1 $(0.01 \mathrm{~nm})$} & $>1$ \\
\hline $\mathrm{GABA}_{\mathrm{A}}$ (agonist site) & Rat cerebellum & {$\left[{ }^{3} \mathrm{H}\right]$ Muscimol (10 nM) } & $>1$ \\
\hline $\mathrm{GABA}_{\mathrm{A}}$ (benzodiazepine central) & Rat brain & {$\left[{ }^{3} \mathrm{H}\right]$ Flunitrazepam (1 nм) } & $>1$ \\
\hline $\mathrm{GABA}_{\mathrm{B}}$ & Rat cerebral cortex & $\begin{array}{l}{\left[{ }^{3} \mathrm{H}\right] \mathrm{GABA}(15 \mathrm{~nm})+\text { Isoguvacine }} \\
\quad(1 \mu \mathrm{M})\end{array}$ & $>1$ \\
\hline Galanin & Rat brain & {$\left[{ }^{125} \mathrm{I}\right]$ Galanin $(0.01 \mathrm{~nm})$} & $>1$ \\
\hline Glutamate (AMPA) & Rat cerebral cortex & {$\left[{ }^{3} \mathrm{H}\right] \mathrm{AMPA}(10 \mathrm{~nm})$} & $>1$ \\
\hline Glutamate (kainate) & Rat brain & {$\left[{ }^{3} \mathrm{H}\right]$ Kainic acid $(5 \mathrm{~nm})$} & $>1$ \\
\hline Glutamate (NMDA agonist site) & Rat cerebral cortex & {$\left[{ }^{3} \mathrm{H}\right] \mathrm{CGP}-39653(5 \mathrm{~nm})$} & $>1$ \\
\hline Glutamate (NMDA glycine site) & Rat cerebral cortex & {$\left[{ }^{3} \mathrm{H}\right] \mathrm{MDL} 105519(1 \mathrm{nM})$} & $>1$ \\
\hline Glycine (strychnine-sensitive) & Rat spinal cord & {$\left[{ }^{3} \mathrm{H}\right]$ Strychnine $(5 \mathrm{~nm})$} & $>1$ \\
\hline Histamine $\mathrm{H}_{1}$ (central) & Guinea pig cerebellum & {$\left[{ }^{3} \mathrm{H}\right]$ Pyrilamine $(2.5 \mathrm{~nm})$} & $>1$ \\
\hline Histamine $\mathrm{H}_{2}$ & Rat cerebral cortex & {$\left[{ }^{3} \mathrm{H}\right]$ Cimetidine $(35 \mathrm{~nm})$} & $>1$ \\
\hline Histamine $\mathrm{H}_{3}$ & Rat brain & {$\left[{ }^{3} \mathrm{H}\right] N$-methyl-histamine $(0.8 \mathrm{~nm})$} & $>1$ \\
\hline Leukotriene $\mathrm{B}_{4}$ & Guinea pig lung & {$\left[{ }^{3} \mathrm{H}\right]$ Leukotriene $\mathrm{B}_{4}(0.1 \mathrm{~nm})$} & $>1$ \\
\hline Leukotriene $\mathrm{D}_{4}$ & Guinea pig lung & {$\left[{ }^{3} \mathrm{H}\right]$ Leukotriene $\mathrm{D}_{4}(0.07 \mathrm{~nm})$} & $>1$ \\
\hline Muscarinic (non-selective) & Rat cerebral cortex & {$\left[{ }^{3} \mathrm{H}\right] \mathrm{QNB}(0.5 \mathrm{~nm})$} & $>1$ \\
\hline Muscarinic $\mathrm{M}_{1}$ & Human recombinant & {$\left[{ }^{3} \mathrm{H}\right] N$-Methylscopolamine $(0.2 \mathrm{nM})$} & $>1$ \\
\hline Muscarinic $\mathrm{M}_{2}$ & Human recombinant & {$\left[{ }^{3} \mathrm{H}\right] N$-Methylscopolamine $(0.2 \mathrm{nM})$} & $>1$ \\
\hline NE transporter & Human recombinant & {$\left[{ }^{3} \mathrm{H}\right]$ Nisoxetine $(0.5 \mathrm{~nm})$} & $>1$ \\
\hline Nicotinic & Rat brain & {$\left[{ }^{3} \mathrm{H}\right] \mathrm{L}-\mathrm{Nicotine}(2.5 \mathrm{~nm})$} & $>1$ \\
\hline Opiate (non-selective) & Rat cerebral cortex & {$\left[{ }^{3} \mathrm{H}\right]$ Naloxone $(1.5 \mathrm{~nm})$} & $>1$ \\
\hline Oxytocin & Rat uterine & {$\left[{ }^{125} \mathrm{I}\right] \mathrm{OVTA}(0.005 \mathrm{~nm})$} & $>1$ \\
\hline PAF & Rabbit platelet & {$\left[{ }^{3} \mathrm{H}\right] \mathrm{PAF}(1 \mathrm{~nm})$} & $>1$ \\
\hline $\mathrm{K}$ channel $\left(\mathrm{K}_{\mathrm{A}}\right)$ & Rat cerebral cortex & {$\left[{ }^{125} \mathrm{I}\right]$ Dendrotoxin $(0.005 \mathrm{~nm})$} & $>1$ \\
\hline $\mathrm{K}$ channel $\left(\mathrm{K}_{\mathrm{ATP}}\right)$ & Rat brain & {$\left[{ }^{3} \mathrm{H}\right]$ Glibenclamide $(0.5 \mathrm{~nm})$} & $>1$ \\
\hline $\mathrm{K}$ channel $\left(\mathrm{K}_{\mathrm{V}}\right)$ & Rat brain & {$\left[{ }^{125} \mathrm{I}\right]$ Charybdotoxin $(0.01 \mathrm{~nm})$} & $>1$ \\
\hline $\mathrm{K}$ channel $\left(\mathrm{SK}_{\mathrm{Ca}}\right)$ & Rat brain & {$\left[{ }^{125} \mathrm{I}\right]$ Apamin $(0.02 \mathrm{nM})$} & $>1$ \\
\hline Serotonin (non-selective) & Rat striatum & {$\left[{ }^{3} \mathrm{H}\right]$ Serotonin $(2.5 \mathrm{~nm})$} & $>1$ \\
\hline Serotonin transporter & Human recombinant & {$\left[{ }^{3} \mathrm{H}\right]$ Imipramine $(1.5 \mathrm{~nm})$} & $>1$ \\
\hline Sigma (non-selective) & Guinea pig brain & {$\left[{ }^{3} \mathrm{H}\right] \mathrm{DTG}(3 \mathrm{~nm})$} & $>1$ \\
\hline Sodium channel site 2 & Rat brain & {$\left[{ }^{3} \mathrm{H}\right]$ Batrachotoxinin $(9 \mathrm{~nm})$} & $>1$ \\
\hline Sodium channel site 2 & Guinea pig heart & {$\left[{ }^{3} \mathrm{H}\right]$ Batrachotoxinin $(9 \mathrm{~nm})$} & 0.87 \\
\hline Testosterone & Rat prostate gland & {$\left[{ }^{3} \mathrm{H}\right] \mathrm{R} 1881(1 \mathrm{nM})$} & $>1$ \\
\hline Thromboxane $\mathrm{A}_{2}$ & Rabbit platelet & {$\left[{ }^{3} \mathrm{H}\right] \mathrm{SQ}-29548(2.5 \mathrm{~nm})$} & $>1$ \\
\hline Vasopressin $\mathrm{V}_{1}$ & Rat liver & {$\left[{ }^{3} \mathrm{H}\right]$ Arg-Vasopressin $(1 \mathrm{~nm})$} & $>1$ \\
\hline VIP & Human recombinant & {$\left[{ }^{3} \mathrm{H}\right] \mathrm{VIP}(0.15 \mathrm{nM})$} & $>1$ \\
\hline
\end{tabular}

completely inhibited at a dose of $0.1 \mathrm{mg} / \mathrm{kg}$. Although FK355 did not decrease tapping time at doses of $0.32-3.2 \mathrm{mg} / \mathrm{kg}$ (Fig. 3B), intracerebroventricularly administered FK355 (1-100 nmol/head) induced a dose-dependent decrease in tapping time (Fig. 3C).
Tissue Distribution in Rats To confirm penetration of FK886 and FK355 into the brain, the distribution of radiolabeled FK886 and FK355 was studied. In cerebrum collected $5 \mathrm{~min}$ after $\left[{ }^{14} \mathrm{C}\right] \mathrm{FK} 886(3.2 \mathrm{mg} / \mathrm{kg}$, intravenously (i.v.)) administration, the radioactivity was $1412 \mathrm{ng}$ equivalents g/tissue, 
Table 4. Effects of FK886 on the Binding Parameters of [ ${ }^{125}$ I]BoltonHunter-Labeled Substance P to Recombinant Human $\mathrm{NK}_{1}$ Receptor

\begin{tabular}{ccc}
\hline \hline Concentration $(\mathrm{nm})$ & $K_{\mathrm{d}}(\mathrm{pm})$ & $B_{\max }(\mathrm{pmol} / \mathrm{mg}$ protein) \\
\hline 0 & $91 \pm 5.4$ & $4.2 \pm 0.25$ \\
0.2 & $100 \pm 6.6$ & $3.6 \pm 0.34^{*}$ \\
0.4 & $110 \pm 2.5^{*}$ & $2.6 \pm 0.14^{* *}$ \\
0.6 & $170 \pm 5.1^{*}$ & $2.5 \pm 0.16^{* *}$ \\
\hline
\end{tabular}

Values are mean \pm S.E.M. obtained from three separate experiments performed in duplicate. $* p<0.05, * * p<0.01 v s$. control value as calculated by Dunnett's multiple comparison test.

which was 0.83 -fold that in plasma (Table 5). On the other hand, radioactivity was not detected in rat cerebrum $5 \mathrm{~min}$ after $\left[{ }^{14} \mathrm{C}\right] \mathrm{FK} 355(1 \mathrm{mg} / \mathrm{kg}$, i.v.) administration.

\section{DISCUSSION}

In this study, we evaluated the pharmacological properties of FK886, a highly potent and specific antagonist of the $\mathrm{NK}_{1}$ receptor. In receptor binding studies, FK886 potently inhibited the binding of radioactive $\mathrm{SP}$ to human $\mathrm{NK}_{1}$ receptors with an $\mathrm{IC}_{50}$ value in the subnanomolar range, a value almost identical to those measured for FK888 and FK355. FK886 had a similar and comparable affinity for dog, ferret, gerbil, and guinea pig $\mathrm{NK}_{1}$ receptors to that for the human receptor, whereas affinity was 30 times lower for the rat $\mathrm{NK}_{1}$ receptor. This may be explained by the fact that the primary sequence of the transmembrane regions of the $\mathrm{NK}_{1}$ receptor protein have seven amino acids that are identical in human and guinea pig, but differ in rat. ${ }^{12,13)}$ While these variations do not affect the potency or efficacy of agonists, they do severely influence the potency of antagonists in different species. The clustering of species-related heterogeneity in the amino acid sequence of the transmembrane regions exactly matches the clustering of species-related differences in the affinities of $\mathrm{NK}_{1}$ antagonists. ${ }^{14)}$ Accordingly, $\mathrm{NK}_{1}$ antagonists have been classified into two types: CP-96,345 (human/guinea pig preference) and

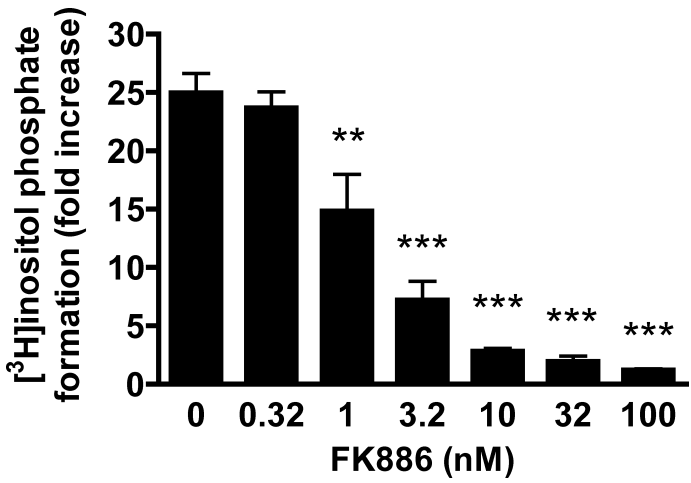

Fig. 2. Antagonist Activity of FK886 on Substance P-Induced Inositol Phosphate Formation in Human $\mathrm{NK}_{1}$ Receptor-Expressing CHO Cells

Results are expressed as the fold increase compared to non-stimulated controls using the mean \pm S.E.M. of three separate experiments. ${ }^{* *} p<0.01,{ }^{* * *} p<0.001 v s$. control by Dunnett's multiple comparison test.

RP67580 (rat/mouse preference) ${ }^{15,16)}$ In this regard, FK886 could be classified as of the human/guinea pig preference type.

FK886 is highly specific for the $\mathrm{NK}_{1}$ receptor, with 250 and $>20000$-fold lower affinities for recombinant human $\mathrm{NK}_{2}$ and $\mathrm{NK}_{3}$ receptors, respectively, than for $\mathrm{NK}_{1}$ receptor, as well as negligible binding affinity $\left(\mathrm{IC}_{50}>1 \mu \mathrm{M}\right)$ at 54 different binding sites, including receptors, ion channels, and transporters.

The potent antagonism of FK886 against the $\mathrm{NK}_{1}$ receptor was further demonstrated by functional assay. While FK886 exhibited no stimulatory effects, it did block $\mathrm{NK}_{1}$ receptor-mediated inositol phosphate formation in human $\mathrm{NK}_{1}$ receptorexpressing $\mathrm{CHO}$ cells with an inhibiting potency comparable to that obtained from the binding study.

Because the brain $\mathrm{NK}_{1}$ receptor is likely to be involved in symptoms of various CNS-related diseases, we examined the effects of FK886 on GR73632-induced foot tapping in gerbils to assess its in vivo antagonistic activity in the CNS. It has
A

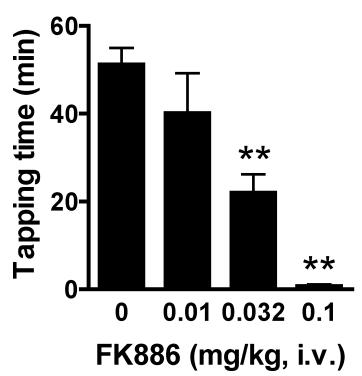

B

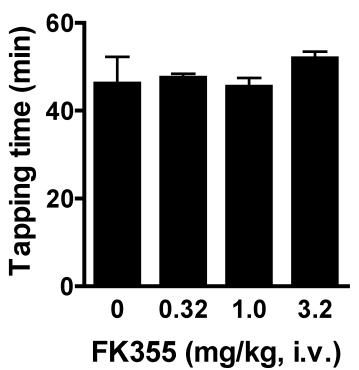

C

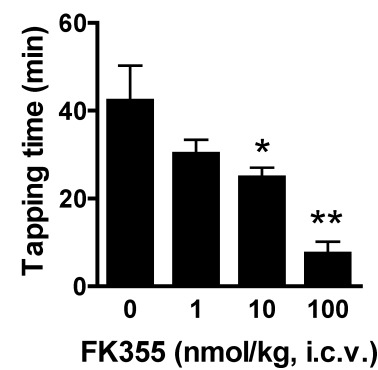

Fig. 3. Effect of Intravenous Administration of FK886 (A), FK355 (B) and Intracerebroventricular Administration of FK355 (C) on Foot Tapping Behavior Induced by GR73632 (10 pmol, i.c.v.) in Gerbils

Drugs were administered $1 \mathrm{~min}$ before GR73632 injection. Values shown are tapping time during the 60 -min observation period (mean \pm S.E.M., $n=5$ ). $* p<0.05$, ** $p<0.01$ vs. vehicle group by Dunnett's multiple comparison test.

Table 5. Tissue Concentrations of Radioactivity $5 \mathrm{~min}$ after Intravenous Administration of $\left[{ }^{14} \mathrm{C}\right] \mathrm{FK} 886$ and $\left[{ }^{14} \mathrm{C}\right] \mathrm{FK} 355$ in Rats

\begin{tabular}{|c|c|c|c|c|}
\hline Compound & Dose (mg/kg) & Plasma (ng eq $/ \mathrm{mL})$ & Cerebrum (ng eq/g tissue) & Cerebrum/plasma ratio \\
\hline FK886 & 3.2 & $1666 \pm 82$ & $1412 \pm 153$ & 0.83 \\
\hline FK355 & 1.0 & $740 \pm 87$ & n.d. & - \\
\hline
\end{tabular}

Values are mean \pm S.E.M. of 3 rats per group. n.d., not detected. 
been reported that foot tapping behavior, which is thought to reflect a fear-related response in gerbils, ${ }^{17,18)}$ could be elicited by direct stimulation of either central $\mathrm{NK}_{1}^{19,20)}$ or $\mathrm{NK}_{3}^{21)}$ receptors. Because direct injection of SP to the brain may stimulate not only $\mathrm{NK}_{1}$ but also other subtypes of tachykinin receptors, a potent and selective $\mathrm{NK}_{1}$ agonist, GR73632, ${ }^{22)}$ was used to determine the $\mathrm{NK}_{1}$ receptor specific foot tapping response.

Intravenous FK886 inhibited the GR73632-induced foot tapping in a dose-dependent manner. The action was potent and long-lasting; even an intravenous bolus injection of $0.1 \mathrm{mg}$ / $\mathrm{kg}$ of FK886 completely inhibited the foot tapping for $60 \mathrm{~min}$. Although we have not determined the brain concentration of FK886 in gerbils, good brain penetration could be confirmed by observing the cerebral distribution of radiolabeled FK886 in rats. Murakami et al. measured the brain receptor occupancy of FK886 in the striatum using ${ }^{11} \mathrm{C}$-labeled FK886 and positron emission tomography, and reported that the FK886 dose in which occupancy in the striatum reached $90 \%$ was about $0.1 \mathrm{mg} / \mathrm{kg}$ in guinea pig and $\operatorname{dog} .{ }^{23)}$ Furthermore, Duffy et al. revealed that $40-90 \%$ receptor occupancy by $\mathrm{NK}_{1}$ antagonists may maximally inhibit foot tapping. ${ }^{24)}$ Taken together, it is reasonable to assume that the inhibition of foot tapping was a result of FK886 penetrating the blood-brain barrier. In contrast, intravenously administered FK355 did not inhibit foot tapping at doses up to $3.2 \mathrm{mg} / \mathrm{kg}$, a result consistent with radiolabeled FK355 not being detected in the cerebrum after intravenous injection. On the other hand, intracerebroventricularly administered FK355 significantly inhibited the foot tapping in a dose-dependent manner. These results indicate that FK886, but not FK355, penetrates the CNS and potently antagonizes the central activation of $\mathrm{NK}_{1}$ receptors when administered peripherally.

In conclusion, FK886 is a potent and centrally active, insurmountable antagonist of the $\mathrm{NK}_{1}$ receptor that can antagonize various $\mathrm{NK}_{1}$ receptor-mediated biological effects in the CNS.

Acknowledgements The authors wish to thank Dr. Yoshiteru Eikyu for his helpful advice, Dr. Toshifumi Shiraga, Dr. Eriko Fujita and Mr. Koji Takeshita for the pharmacokinetics data, and Dr. Kenji Tabata and Dr. Toshio Teramura for their patience and encouragement.

\section{REFERENCES}

1) Maggi CA, Patacchini R, Rovero P, Giachetti A. Tachykinin receptors and tachykinin receptor antagonists. J. Auton. Pharmacol., 13, 23-93 (1993).

2) Khawaja AM, Rogers DF. Tachykinins: receptor to effector. Int. J. Biochem. Cell Biol., 28, 721-738 (1996).

3) Duffy RA. Potential therapeutic targets for neurokinin-1 receptor antagonists. Expert Opin. Emerg. Drugs, 9, 9-21 (2004).

4) Alvaro G, Di Fabio R. Neurokinin 1 receptor antagonists-current prospects. Curr. Opin. Drug Discov. Devel., 10, 613-621 (2007).

5) Rupniak NM, Kramer MS. Discovery of the antidepressant and anti-emetic efficacy of substance $\mathrm{P}$ receptor $\left(\mathrm{NK}_{1}\right)$ antagonists. Trends Pharmacol. Sci., 20, 485-490 (1999).

6) Huang SC, Korlipara VL. Neurokinin-1 receptor antagonists: a comprehensive patent survey. Expert Opin. Ther. Pat., 20, 10191045 (2010).

7) Manabe $T$, Miyake H, Shingenaga S, Murano K, Matsuda H, Karino M, Fujii T. Design and synthesis of new nonpeptide NK1 antagonists by chemical modification of FK888. ACS Meeting 2000, 220th, Washington D.C. (MEDI 121) (2000).

8) Eikyu Y, Take K, Shigenaga S, Azami H, Kayakiri N, Ishida J, Morita M, Sasaki H, Terasaka T, Manabe T, Imazumi K, Okada M, Ohta M. Creation of Potent, Orally Active and Highly CNS-Penetrant $\mathrm{NK}_{1}$ Receptor Antagonists. AFMC International Medicinal Chemistry Symposium 2011, 8th, Tokyo (Abs 2P-179) (2011).

9) Aramori I, Morikawa N, Zenkoh J, O’Donnell N, Iwami M, Kojo H, Notsu Y, Okuhara M, Ono S, Nakanishi S. Subtype- and speciesselectivity of a tachykinin receptor antagonist, FK888, for cloned rat and human tachykinin receptors. Eur. J. Pharmacol., 269, 277-281 (1994).

10) Vauquelin G, Van Liefde I, Birzbier BB, Vanderheyden PM. New insights in insurmountable antagonism. Fundam. Clin. Pharmacol., 16, 263-272 (2002).

11) Kenakin $T$, Jenkinson S, Watson C. Determining the potency and molecular mechanism of action of insurmountable antagonists. $J$. Pharmacol. Exp. Ther., 319, 710-723 (2006).

12) Engberg S, Ahlstedt I, Leffler A, Lindström E, Kristensson E, Svensson A, Påhlman I, Johansson A, Drmota T, von Mentzer B. Molecular cloning, mutations and effects of $\mathrm{NK}_{1}$ receptor antagonists reveal the human-like pharmacology of gerbil $\mathrm{NK}_{1}$ receptors. Biochem. Pharmacol., 73, 259-269 (2007).

13) Gorbulev V, Akhundova A, Luzius H, Fahrenholz F. Molecular cloning of substance $\mathrm{P}$ receptor cDNA from guinea-pig uterus. Biochim. Biophys. Acta, 1131, 99-102 (1992).

14) Saria A. The tachykinin $\mathrm{NK}_{1}$ receptor in the brain: pharmacology and putative functions. Eur. J. Pharmacol., 375, 51-60 (1999).

15) Fong TM, Yu H, Strader CD. Molecular basis for the species selectivity of the neurokinin-1 receptor antagonists CP-96,345 and RP67580. J. Biol. Chem., 267, 25668-25671 (1992).

16) Sachais BS, Snider RM, Lowe JA 3rd, Krause JE. Molecular basis for the species selectivity of the substance P antagonist CP-96,345. J. Biol. Chem., 268, 2319-2323 (1993).

17) Ballard TM, Sänger S, Higgins GA. Inhibition of shock-induced foot tapping behaviour in the gerbil by a tachykinin $\mathrm{NK}_{1}$ receptor antagonist. Eur. J. Pharmacol., 412, 255-264 (2001).

18) Rupniak NM, Webb JK, Fisher A, Smith D, Boyce S. The substance $\mathrm{P}\left(\mathrm{NK}_{1}\right)$ receptor antagonist L-760735 inhibits fear conditioning in gerbils. Neuropharmacology, 44, 516-523 (2003).

19) Bristow LJ, Young L. Chromodacryorrhea and repetitive hind paw tapping: models of peripheral and central tachykinin $\mathrm{NK}_{1}$ receptor activation in gerbils. Eur. J. Pharmacol., 253, 245-252 (1994).

20) Rupniak NM, Williams AR. Differential inhibition of foot tapping and chromodacryorrhoea in gerbils by CNS penetrant and nonpenetrant tachykinin $\mathrm{NK}_{1}$ receptor antagonists. Eur. J. Pharmacol., 265, 179-183 (1994).

21) Sundqvist M, Kristensson E, Adolfsson R, Leffler A, Ahlstedt I, Engberg S, Drmota T, Sigfridsson K, Jussila R, de Verdier J, Novén A, Johansson A, Påhlman I, von Mentzer B, Lindström E. Senktideinduced gerbil foot tapping behaviour is blocked by selective tachykinin NK1 and NK3 receptor antagonists. Eur. J. Pharmacol., 577, 78-86 (2007).

22) Hagan RM, Ireland SJ, Jordan CC, Beresford IJ, Deal MJ, Ward P. Receptor-selective, peptidase-resistant agonists at neurokinin NK-1 and NK-2 receptors: new tools for investigating neurokinin function. Neuropeptides, 19, 127-135 (1991).

23) Murakami Y, Noda A, Osoda K, Matsuya T, Sogabe H, Take K, Matsuoka N, Nishimura S. Synthesis of ${ }^{11} \mathrm{C}$-labeled FK886, a novel NK1 receptor ligand and the pharmacodynamic PET study in animals. SNM Annual Meeting, May 2007, J. Nucl. Med., 48 (Suppl. 2), 301P (2007).

24) Duffy RA, Varty GB, Morgan CA, Lachowicz JE. Correlation of neurokinin $(\mathrm{NK}) 1$ receptor occupancy in gerbil striatum with behavioral effects of NK1 antagonists. J. Pharmacol. Exp. Ther., 301, 536-542 (2002). 